\title{
ANALISIS DESAIN SISTEM PEMBANGKIT LISTRIK TENAGA SURYA KAPASITAS 150 WP SEBAGAI SUPLAI ENERGI PADA FOTOBIOREAKTOR MIKROALGA
}

\author{
Fifin Hindarti 1), Endah Ayuningtyas ${ }^{2)}$ \\ ${ }^{1)}$ Fakultas Teknologi Industri, Institut Teknologi Yogyakarta ${ }^{2)}$ Fakultas Ilmu Lingkungan, Institut Teknologi \\ Yogyakarta \\ email: viendarti@ity.ac.id ${ }^{1)}$, EndahA25@ gmail.com ${ }^{2)}$
}

\begin{abstract}
ABSTRAK
Energi baru dan terbarukan bukan hanya merupakan energi alternatif yang dapat memenuhi kebutuhan energi yang semakin meningkat, tapi juga merupakan energi hijau yang tidak menimbulkan dampak berbahaya bagi manusia dan lingkungan seperti pada energi yang berasal dari fosil. Penerapan sel surya sebagai sumber energi listrik pada fotobioreaktor tempat budidaya mikroalga merupakan salah satu upaya untuk mengembangkan energi baru dan terbarukan yang ramah lingkungan. Penelitian ini merupakan inovasi teknologi dalam bidang budidaya mikroalga menggunakan panel surya sebagai pengkonversi energi matahari menjadi energi listrik.

Perancangan pembangkit listrik tenaga surya skala kecil yang akan digunakan untuk mensuplai kebutuhan energi dari fotobioreaktor adalah menggunakan panel surya dengan kapasitas $150 \mathrm{wp}$. Panel surya sebagai pengkonversi energi, solar charge controller sebagai pengatur keseimbangan arus listrik. Pelaksanaan penelitian ini terdiri dari beberapa tahap yaitu: tahap pengumpulan data awal, tahap pengembangan sistem, dan tahap pengumpulan data penelitian. Kebutuhan energi yang akan dipenuhi adalah untuk menghidupkan lampu dan aerator,

Hasil pengujian sistem pembangkit listrik tenaga surya yang telah dirancang menunjukkan bahwa daya keluaran rata-rata mencapai 45,18 Watt dan arus yang didapatkan sebesar 3,7 Ampere.

Kata kunci: Energi alternatif, Sel Surya, Fotobioreaktor, Mikroalga
\end{abstract}

\section{ANALYSIS DESIGN OF 150 WP CAPACITY OF SOLAR POWER PLANT AS ENERGY SUPPLY IN MICROALGAE PHOTOBIOREACTORS}

\begin{abstract}
New and renewable energy is not only an alternative energy that can meet the increasing energy needs, but it is also a green energy that does not cause harmful impacts on humans and the environment such as on energy derived from fossils. The application of solar cells as a source of electrical energy in photobioreactors at the microalgae cultivation is one of the efforts to develop the new and renewable energy that is environmentally friendly. This research is a technological innovation in the field of microalgae cultivation using solar panels as a converter of solar energy into electrical energy.

The design of small scale solar power plants to supply the energy needs of photobioreactors is to use solar panels with a capacity of $150 \mathrm{wp}$. Solar panels are functioned as energy converters, and solar charge controllers are functioned as regulators of electric current balance. The implementation of this research consisted of several stages, namely: the initial data collection stage, the system development stage, and the research data collection stage. The energy needs are used to turn on lamps and aerators,

The test results of solar power generation systems that have been designed show that the average output power reaches 45.18 Watt and the current obtained is 3.7 Amperes.

Keywords: Alternative energy, Solar Cells, Photobioreactors, Microalgae
\end{abstract}

\section{PENDAHULUAN}

Saat ini energi baru dan terbarukan bukan lagi merupakan suatu hal yang asing bagi kita. Hampir semua negara di dunia ini sedang bersaing untuk melakukan penelitian dalam bidang pengembangan energi baru dan terbarukan dalam upaya untuk menghadapi krisis energi dimasa depan karena adanya penurunan jumlah energi yang berasal dari fosil sejalan dengan peningkatan kebutuhan manusia akan energi.

Penanggulangan terhadap masalah lingkungan global seperti pemanasan global, saat ini sangat mendapat perhatian. Indonesia sebagai negara tropis mempunyai potensi energi surya yang tinggi dengan radiasi harian rata-rata (insolasi) sebesar 4,5 kWh/m2/hari. Energi surya merupakan energi ramah lingkungan, sehingga tidak mengherankan bahwa energi terbarukan saat ini dikriteriakan sebagai 
energi masa depan dan dapat diterima oleh masyarakat modern sehingga sudah mulai dikembangkan oleh beberapa negara maju.

Besarnya potensi penggunaan tenaga matahari sebagai pembangit energi dapat diaplikasikan dalam berbagai bidang, termasuk dalam budidaya biomassa bahan baku biodiesel, khususnya kultivasi atau budidaya mikroalga yang memerlukan pencahayaan dan aerasi agar diperoleh biomassa dengan kualitas dan kuantitas yang baik.

Pengembangan sumber energi alternatif terbarukan sangat diperlukan untuk memenuhi kebutuhan energi dunia seiring menipisnya persediaan energi bahan bakar berbasis fosil. Menjawab tantangan di atas, secara teknis mikroalga sangat berpotensi untuk dikembangkan menjadi sumber produksi biodisel yang diharapkan mampu memenuhi kebutuhan energi bahan bakar dunia. Selain sebagai bahan baku biodiesel, mikroalga juga berpotensi untuk dikonversi menjadi bentuk energi lainnya seperti bioethanol, biometanol maupun syngas melalui teknologi konversi seperti pirolisis, gasifikasi maupun fermentasi. Namun demikian, penelitian-penelitian lanjutan perlu terus dilakukan ke arah pengembangan jenis mikroalga yang mengandung konsentrasi minyak yang tinggi namun juga mampu menurunkan derajat asam lemak tak jenuhnya sehingga biodisel tidak mudah teroksidasi saat penyimpanan. (Sarman Oktovianus Gultom, 2018).

Teknologi produksi mikroalga secara umum dibagi menjadi dua, yaitu sistem tertutup dan sistem terbuka. Sistem terbuka (open raceway pond) dioperasikan di luar ruangan dan bergantung pada sinar cahaya matahari alami untuk penyinarannya. Sistem tertutup (fotobioreaktor) dapat dioperasikan di dalam atau di luar ruangan, namun biasanya diletakkan di luar ruangan, agar dapat memanfaatkan sinar cahaya matahari (Ojamae, 2011).

Pemanfaatan energi surya untuk suplai tenaga listrik fotobioreaktor merupakan salah satu solusi untuk mencapai sistem produksi mikroalga yang menggunakan energi terbarukan. Pada pengoperasian fotobioreaktor diperlukan sumber tenaga untuk menyuplai energi dengan sistem kontrol, monitoring dan peralatan pendukung lain yang diperlukan. Input dan output energi yang digunakan dalam penggunaan fotobioreaktor ini dapat diketahui selama masa eksperimen sehingga didapatkan data energi yang digunakan dan yang dihasilkan. Dalam penelitian ini digunakan spesies Spirulina Sp karena relatif mudah dikultur dalam waktu singkat, dan spesies tersebut memiliki potensi untuk bio bahan bakar

Berdasarkan permasalahan di atas maka dirasa perlu untuk melakukan studi kelayakan untuk dapat membuat analisis tentang kemungkinanan menerapkan PLTS sebagai sumber energi listrik untuk pencahayaan dan sistem aerasi pada budidaya mikroalga.

Dalam penelitian ini akan menganalisis desain hasil rancangan sistem pembangkit listrik tenaga surya kapasitas 150 WP. Dengan tujuan penelitian untuk menghitung karakteristik pembangkit listrik tenaga surya kapasitas 150 WP dan menghitung daya maksimal yang dihasilkan oleh pembangkit listrik tenaga surya yang dirancang. Sehingga dapat dianalisis unjuk kerja dari desain sistem pembangkit listrik tenaga surya kapasitas $150 \mathrm{WP}$.

Urgensi atau arti penting dari penelitian ini adalah mendukung upaya pemanfaatan sumber daya alam lokal (mikrolaga) sebagai bahan baku penghasil biodiesel, serta menghasilkan rancangan fotobioreaktor tenaga matahari yang hemat energi dan dengan hasil tingkat konsentrasi mikroalga yang tinggi, sehingga dapat diterapkan untuk budidaya mikroalga dalam industri kecil.

\section{TINJAUAN PUSTAKA}

\section{Teknologi Energi Surya}

Energi surya merupakan salah satu sumber energi terbarukan yang dimanfaatkan melalui dua macam teknologi yaitu teknologi fotovoltaik (PV) dan teknologi fototermik (surya termal). Teknologi PV mengkonversi langsung cahaya matahari menjadi listrik melalui perangkat semikonduktor yang disebut sel surya, sedangkan teknologi surya termal memanfaatkan panas dari radiasi matahari dengan menggunakan alat pengumpul panas atau yang biasa disebut kolektor surya. (Rislima Sitompul, 2011)

\section{Komponen Utama PLTS \\ Panel Surya (Solar Panel)}

Sel surya atau sel photovoltaic merupakan suatu alat yang dapat mengubah energi radiasi matahari secara langsung menjadi energi listrik. Pada dasarnya sel tersebut berjenis diode yang tersusun atas $\mathrm{P}-$ $\mathrm{N}$ junction. Sel surya photovoltaic yang dibuat dari bahan semi konduktor yang diproses sedemikian rupa, yang dapat menghasilkan listrik arus searah (DC). Dalam penggunaannya, sel-sel surya itu dihubungkan satu sama lain, sejajar atau seri, tergantung dari penggunaannya, guna menghasilkan daya dengan kombinasi tegangan dan arus yang dikehendaki. Sebuah panel surya terbuat dari banyak sel 
surya. Sel tersambung secara elektrik untuk memberikan arus dan tegangan tertentu. Masing-masing sel di enkapsulasi untuk mengisolasi dan melindungi dari kelembaban dan korosi. (Heru Wahyudi, 2010).

\section{Solar Charge Controller}

Solar Charge Controller adalah komponen yang berfungsi sebagai pengatur arus listrik (Current Regulator) baik terhadap arus yang masuk dari panel PV maupun arus beban keluar / digunakan. Bekerja untuk menjaga baterai dari pengisian yang berlebihan (OverCharge), Ini mengatur tegangan dan arus dari panel surya ke baterai. Sebagian besar Solar PV 12 Volt menghasilkan tegangan keluar (V-Out) sekitar 16 sampai 20 volt DC, jadi jika tidak ada peraturan, baterai akan rusak dari pengisian tegangan yang berlebihan yang umumnya baterai 12Volt membutuhkan tegangan pengisian (Charge) sekitar 1314,8 volt (Tergantung Tipe Battery) untuk dapat terisi penuh. (http://solarsuryaindonesia.com)

\section{Inverter}

Inverter adalah perangkat elektrik yang digunakan untuk mengubah arus listrik searah (DC Direct Current) menjadi arus listrik bolak balik (AC - Alternating Current). Inverter mengkonversi arus DC 12/24 volt dari sumber arus backup seperti batere, panel surya/ solar cell menjadi AC 220 volt setara PLN. Dalam Pembangkit Listrik Tenaga Surya (PLTS), inverter diperlukan untuk menyediakan sumber arus AC untuk perangkat listrik seperti lampu, televisi, pompa air, dan lain-lain. (http://solarsuryaindonesia.com)

\section{Baterai}

Baterai merupakan alat penyimpan daya yang dihasilkan oleh panel surya yang tidak segera digunakan oleh beban. Daya yang disimpan dapat digunakan saat periode radiasi matahari rendah atau pada malam hari. Baterai berfungsi menyimpan listrik dalam bentuk daya kimia. Baterai yang paling biasa digunakan dalam aplikasi surya adalah baterai yang bebas pemeliharaan bertimbal asam (maintenance-free lead-acid batteries), yang juga dinamakan baterai recombinant atau VRLA (klep pengatur asam timbal atau valve regulated lead acid).

Baterai terbentuk oleh sekelompok elemen atau sel yang diletakan secara seri. Baterai timbalasam terdiri dari dua elektroda timbal yang berada dalam larutan elektrolit air dan asam sulfat. Perbedaan potensial sekitar 2 volt terjadi di antara elektroda, tergantung pada nilai seketika kondisi penyimpanan baterai. Baterai yang paling umum dalam aplikasi surya fotovoltaik mempunyai tegangan nominal sebanyak 12 volt atau 24 volt. (Heru Wahyudi, 2010).

\section{Dasar-Dasar Perencanaan PLTS}

Perencanaan PLTS secara sederhana memerlukan tiga masukan :

a.Karakteristrik modul yang digunakan

b. Radiasi surya ditempat penerapan

c.Besar beban peralatan yang akan dipasok listrik.

Sistem sel surya dapat dibangun dalam berbagai ukuran atas dasar kebutuhan energinya. Selanjutnya sistem sel surya itu dapat dikembangkan dan ditingkatkan dengan mudah. Misalnya, bila kebutuhan energi semakin meningkat, cukup dengan jalan menambahkan modul surya, tentunya jika sumber dananya memungkinkan. Selain itu, sistem sel surya gampang untuk dipindahkan bila dipandang perlu. Maka kesimpulannya, keunggulan sistem sel surya itu keandalannya tinggi, biaya operasinya rendah, ramah lingkungan, berbentuk modul, dan biaya konstruksinya rendah

\section{Fotobioreaktor}

Fotobioreaktor (PBR) adalah sebuah wadah tertutup (terbebas dari kontak udara luar) untuk membiakkan sel bakteri/ fitoplankton dimana energi disuplay ke dalam wadah melalui energi cahaya2). Secara umum faktor utama yang diperhitungkan dalam perakitan suatu fotobioreaktor ada dua hal yaitu penerapan biaya operasional yang efektif dan konsistensi dalam menjaga kualitas biomass yang dihasilkan (Arif Dwi Santoso, 2010).

Fotobioreaktor umumnya bersifat tertutup sehingga sistem tersebut dimaksudkan untuk mengatasi densitas sel yang rendah, isu ontaminasi, kehilangan air akibat penguapan, dan kebutuhan lahan yang luas. Fotobioreaktor sangat fleksibel dengan meletakkan di dalam ruangan dengan bantuan cahaya buatan atau di luar ruangan dengan bantuan cahaya matahari (Arief Budiman, dkk, 2019).

Menurut Singh dan Sharma (dalam Sari Afriani, dkk, 2018) menerangkan bahwa, fotobioreaktor dapat digambarkan sebagai sebuah bejana kultur tertutup yang diberi cahaya dan dirancang untuk 
mengontrol produksi biomassa. Keunggulan dari fotobioreaktor selain meminimalkan kontaminasi juga memungkinkan monokultur mikroalga yang terkontrol terhadap kondisi cahaya, suhu dan $\mathrm{pH}$. Fotobioreaktor dapat mengendalikan hilangnya $\mathrm{CO} 2$ yang lebih sedikit, mencegah penguapan air dan menghasilkan pertumbuhan sel yang lebih tinggi.

\section{Mikroalga}

Mikroalga hijau dan Cyanobacteria merupakan kelompok besar organisme fotosintetik. Kelompok ini hidup di seluruh biosfer secara luas, pada berbagai kondisi perairan, baik air tawar maupun perairan bersalinitas ekstrim, bahkan di tempat-tempat terestrial. Keunikannya yang membedakan mikroalga dari mikroorganisme lainnya adalah adanya klorofil dan memiliki kemampuan fotosintesis pada setiap sel mikroalga tunggal. Dalam istilah ekonomi, mikroalga dapat dilihat sebagai mikroorganisme yang mampu menghasilkan senyawa yang sangat berharga.Komponen utama sel mikroalga hijau yang sangat berharga meliputi dinding sel, kloroplas yang mengandung klorofil dan pigmen pigmen alami, pyrenoid, daerah padat yang mengandung granula pati pada dinding sel, dan asam lemak tak jenuh ganda dari sumber daya yang relatif murah (Carvalho dan Malcata dalam Astri Rinanti dan Ronny Purwadi 2018).

Faktor-faktor yang mempengaruhi pertumbuhan mikroalga, diantaranya faktor abiotik (cahaya matahari, temperatur, nutrisi, $\mathrm{O} 2, \mathrm{CO} 2, \mathrm{pH}$, salinitas), faktor biotik (bakteri, jamur, virus, dan kompetisi dengan mikroalga lain), serta faktor teknik (cara pemanenan, dll). Mikroalga dapat tumbuh dengan sangat cepat pada kondisi iklim yang tepat. Umumnya, mikroalga menduplikasikan diri dalam jangka waktu 24 jam atau bahkan 3,5 jam selama fasa pertumbuhan eksponensial. Pertumbuhan mikroalga pun sangat dipengaruhi oleh konsentrasi gas CO2 di dalam gas pencemar (Hadiyanto, 2014).

Alga, khususnya mikroalga uniseluler berwarna hijau sebenarnya telah lama diketahui sebagai sumber bahan baku yang potensial bagi produksi bahan bakar nabati (Pitman, dalam Hadiyanto dan Nais P.A, 2018). Dengan maraknya penelitian untuk mencari sumber energi alternatif, mikroalga mempunyai prospek yang sangat baik untuk dikembangkan sebagai salah satu kandidat bahan baku penghasil biofuel. Mikroalga dipilih karena memiliki kemampuan tumbuh dengan cepat serta tidak memerlukan area yang luas untuk kegiatan produksi. Di samping itu mikroalga mempunyai kemampuan untuk menyerap karbondioksida sehingga dapat mengurangi efek rumah kaca (Widjaja, dalam Hadiyanto dan Nais P.A, 2018).

Mikroalga spirulina sp. mempunyai kandungan protein $60-71 \%$ (dari berat kering), lemak $8 \%$, karbohidrat $16 \%$, vitamin $1,6 \%$, chlorophyll-a $18 \%$, C-phycocyanin $17 \%, \beta$-carotene $17 \%$ dan $20-30 \%$ $\gamma$-linoleaic (dari total as.lemak). Spirulina sp. memiliki kandungan nutrisi yang baik seperti kandungan vitamin dan mineral sehingga digunakan sebagai bahan makanan kesehatan. Beberapa fungsi dari spirulina diantaranya dapat meningkatkan aktivitas antivirus, mengurangi kadar kolesterol dalam tubuh manusia, menjaga sistem imunitas tubuh (Anonim dalam Rahayu Kusdarwati,dkk, 2011).

\section{METODE PENELITIAN}

Penelitian dengan judul “Analisis Desain Sistem Pembangkit Listrik Tenaga Surya Kapasitas 150 Wp Sebagai Suplay Pada Fotobioreaktor Mikroalga” merupakan aplikasi dari sel surya sebagai sumber energi pada fotobioreaktor yang merupakan tempat budidaya mikroalga dengan pemanfaatan energi terbarukan, yaitu memanfaatkan tenaga radiasi matahari dengan menggunakan panel surya sebagai pengkonversi energi matahari menjadi energi listrik yang digunakan untuk menyuplai kebutuhan daya pada pengoperasian fotobioreaktor mikroalga (Spirulina Sp).

Tahapan dalam penelitian ini meliputi :

1. Tahap perancangan alat atau reaktor meliputi :

a. Dimensi reaktor dengan jumlah reaktor, sebanyak 3 reaktor.

b. Perhitungan total beban yang akan disuplai oleh panel surya

c. Penentuan kapasitas dan jenis panel surya.

d. Perhitungan kebutuhan baterai, inverter dan peralatan pendukung.

e. Dari segi estetika, desain alat agar dapat dibuat sedemikian rupa sehingga rapi, menarik dan aman dalam penggunaannya

f. Perancangan sistem secara keseluruhan, yaitu fotobioreaktor yang dirangkai dengan sumber energi dari panel surya.

2. Tahap Implementasi, pada tahap ini instalasi fotobioreaktor dan solar cell dirancang sesuai tahap perancangan.

3. Tahap Pengujian 
Tahapan pengujian dilakukan untuk menegtahui kinerja pembangkit listrik tenaga matahari 150 WP sebagai suplai energi untuk fotobioreaktor mikroalga. Pengujian dilakukan untuk mengetahui tegangan dan arus input panel surya serta untuk mengetahui tegangan dan arus output dari baterai.

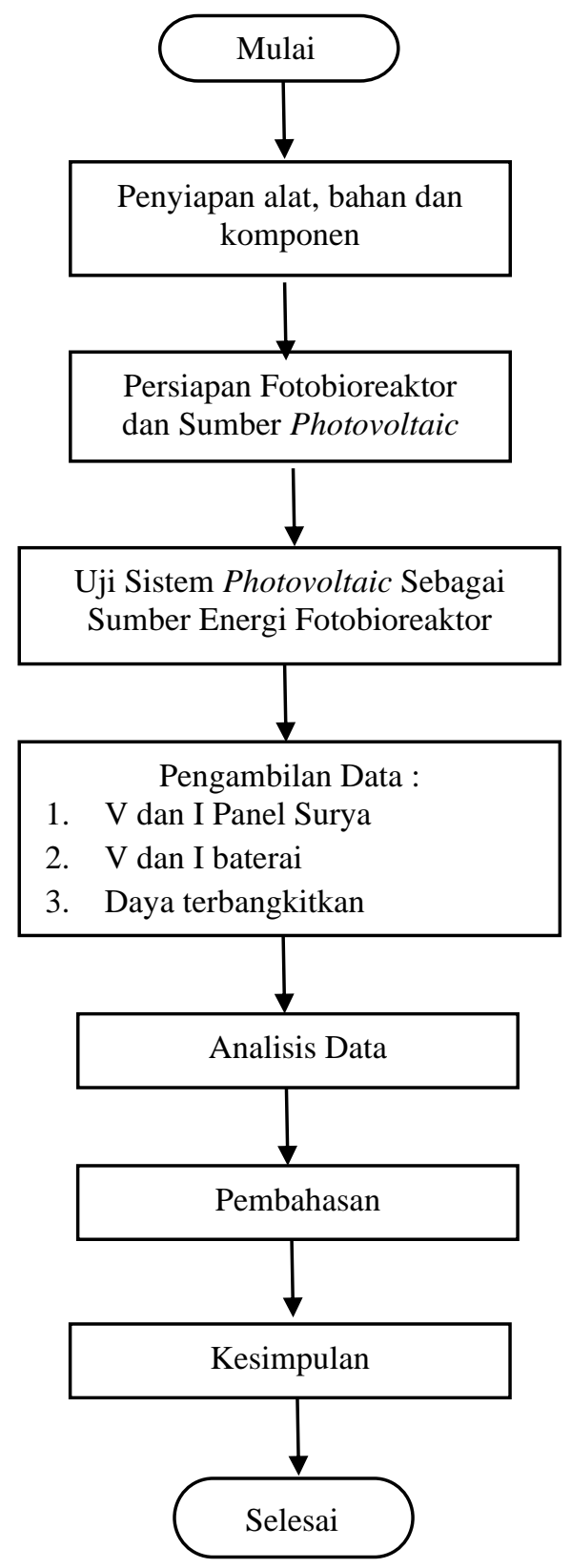

Metodologi yang digunakan dalam desain analisis pembangkit listrik tenaga matahari $150 \mathrm{WP}$ sebagai suplai energi untuk fotobioreaktor mikroalga dapat digambarkan dalam bentuk diagram alir (flowchart) yang sistematis seperti Gambar 1

\section{HASIL DAN PEMBAHASAN}

Data dalam penelitian ini diperoleh dari pengujian panel surya tipe monocrystalline $150 \mathrm{Wp}$. Penelitian ini bertujuan untuk mengetahui kinerja panel surya tipe monocrystalline $150 \mathrm{Wp}$ dalam menghasilkan energi listrik sebagai suplai energi pada fotobioreaktor mikroalga berupa arus, tegangan, dan daya untuk pengisian baterai berkapasitas $12 \mathrm{~V} 7 \mathrm{Ah}$.

Pengambilan data penelitian dilakukan pada pukul 06.00 wib - 18.00 wib. Pengujian untuk mengetahui arus, tegangan dan daya dalam penelitian ini menggunakan beberapa komponen yaitu panel surya monocrystalline $150 \mathrm{Wp}$, solar charger controller, baterai, voltmeter dan ampermeter.

Pengujian panel surya tipe monocrystalline $150 \mathrm{Wp}$ sebagai sumber energi alternatif untuk mensuplai fotobioreaktor sebagai tempat budidaya mikroalga dilakukan selama 3 (tiga hari), dan data diambil setiap jam untuk 12 jam. Besaran arus dan tegangan dari panel surya dapat dibaca langsung 
pada alat ukur ampermeter dan voltmeter yang terpasang pada reaktor dan hasilnya dapat dicatat dan ditabelkan.

Berikut ini data pengujian sistem panel surya tipe monocrystalline $150 \mathrm{Wp}$ sebagai sumber energi alternatif.

Hari Pertama

\begin{tabular}{cccccccc}
\hline \multirow{2}{*}{ No } & \multirow{2}{*}{ Jam } & \multicolumn{2}{c}{ Data Pengukuran Panel Surya } & \multicolumn{2}{c}{ Data Pengukuran Beban } \\
\cline { 3 - 8 } & & Tegangan & Arus & Daya Solarcell & Tegangan & Arus & Daya Beban \\
\hline 1 & 06.00 & 12,6 & 0 & 0 & 11,8 & 3,7 & 43,66 \\
\hline 2 & 07.00 & 12,3 & 0 & 0 & 11,5 & 3,7 & 42,55 \\
\hline 3 & 08.00 & 12,7 & 0 & 0 & 11,7 & 3,7 & 43,29 \\
\hline 4 & 09.00 & 13,1 & 5 & 65,5 & 12,1 & 3,7 & 44,77 \\
\hline 5 & 10.00 & 13,5 & 6,5 & 87,75 & 12,5 & 3,7 & 46,25 \\
\hline 6 & 11.00 & 13,7 & 7 & 95,9 & 12,7 & 3,7 & 46,99 \\
\hline 7 & 12.00 & 13,9 & 7,2 & 100,08 & 12,9 & 3,7 & 47,73 \\
\hline 8 & 13.00 & 14,1 & 7,5 & 105,75 & 13 & 3,7 & 48,1 \\
\hline 9 & 14.00 & 13,6 & 2 & 27,2 & 12,5 & 3,7 & 46,25 \\
\hline 10 & 15.00 & 13,5 & 2 & 27 & 12,5 & 3,7 & 46,25 \\
\hline 11 & 16.00 & 13,1 & 1 & 13,1 & 12,2 & 3,7 & 45,14 \\
\hline 12 & 17.00 & 12,8 & 0 & 0 & 11,9 & 3,7 & 44,03 \\
\hline 13 & 18.00 & 12,4 & 0 & 0 & 11,6 & 3,7 & 42,92 \\
\hline \multicolumn{2}{l}{ Rata-rata } & 13,18 & 2,94 & 40,17 & 12,22 & 3,7 & 45,22 \\
\hline & & & & & & &
\end{tabular}

Hari kedua

\begin{tabular}{cccccccc}
\hline \multirow{2}{*}{ No } & \multirow{3}{*}{ Jam } & \multicolumn{3}{c}{ Data Pengukuran Panel Surya } & \multicolumn{3}{c}{ Data Pengukuran Beban } \\
\cline { 3 - 8 } & & Tegangan & Arus & Daya Solarcell & Tegangan & Arus & Daya Beban \\
\hline 1 & 06.00 & 12,5 & 0 & 0 & 11,7 & 3,7 & 43,29 \\
\hline 2 & 07.00 & 12,3 & 0 & 0 & 11,5 & 3,7 & 42,55 \\
\hline 3 & 08.00 & 12,8 & 0 & 0 & 11,7 & 3,7 & 43,29 \\
\hline 4 & 09.00 & 13,1 & 5 & 65,5 & 12,1 & 3,7 & 44,77 \\
\hline 5 & 10.00 & 13,4 & 6,5 & 87,1 & 12,4 & 3,7 & 45,88 \\
\hline 6 & 11.00 & 13,7 & 7 & 95,9 & 12,7 & 3,7 & 46,99 \\
\hline 7 & 12.00 & 13,9 & 7,1 & 98,69 & 12,9 & 3,7 & 47,73 \\
\hline 8 & 13.00 & 14,0 & 7,4 & 103,6 & 13 & 3,7 & 48,1 \\
\hline 9 & 14.00 & 13,5 & 2 & 27 & 12,5 & 3,7 & 46,25 \\
\hline 10 & 15.00 & 13,5 & 2 & 27 & 12,5 & 3,7 & 46,25 \\
\hline 11 & 16.00 & 13,2 & 1 & 13,2 & 12,3 & 3,7 & 45,51 \\
\hline 12 & 17.00 & 12,8 & 0 & 0 & 12 & 3,7 & 44,4 \\
\hline 13 & 18.00 & 12,4 & 0 & 0 & 11,6 & 3,7 & 42,92 \\
\hline Rata-rata & 13,16 & 2,92 & 39,84 & 12,22 & 3,7 & 45,22 \\
\hline & & & & & & & \\
\hline
\end{tabular}

63 |Analisis Desain Sistem Pembangkit Listrik Tenaga Surya Kapasitas 150 Wp sebagai Suplai Energi pada Fotobioreaktor Mikroalga 


Hari ketiga
\begin{tabular}{ccccccccc}
\hline \multirow{2}{*}{ No Jam } & Jata Pengukuran Panel Surya & \multicolumn{2}{c}{ Data Pengukuran Beban } \\
\cline { 3 - 9 } & & Tegangan & Arus & Daya & Tegangan & Arus & Daya \\
\hline 1 & 06.00 & 12,5 & 0 & 0 & 11,6 & 3,7 & 42,92 \\
\hline 2 & 07.00 & 12,5 & 0 & 0 & 11,6 & 3,7 & 42,92 \\
\hline 3 & 08.00 & 12,6 & 0 & 0 & 11,7 & 3.7 & 43,29 \\
\hline 4 & 09.00 & 13,0 & 5,00 & 65,00 & 12,1 & 3,7 & 44,77 \\
\hline 5 & 10.00 & 13,4 & 6,50 & 87,10 & 12,5 & 3,7 & 46,25 \\
\hline 6 & 11.00 & 13,7 & 6,50 & 89,05 & 12,7 & 3.7 & 46,99 \\
\hline 7 & 12.00 & 13,8 & 7,00 & 96,60 & 12,8 & 3,7 & 47,36 \\
\hline 8 & 13.00 & 14,0 & 7,50 & 105,00 & 13,0 & 3,7 & 48,1 \\
\hline 9 & 14.00 & 13,6 & 2,50 & 34,00 & 12,6 & 3.7 & 46,62 \\
\hline 10 & 15.00 & 13,6 & 2,00 & 27,20 & 12,5 & 3,7 & 46,25 \\
\hline 11 & 16.00 & 13,0 & 1 & 13,00 & 12,3 & 3,7 & 45,51 \\
\hline 12 & 17.00 & 12,8 & 0 & 0 & 11,9 & 3.7 & 43,29 \\
\hline 13 & 18.00 & 12,4 & 0 & 0 & 11,6 & 3,7 & 42,18 \\
\hline Rata-rata & 13,1 & 2,9 & 39,77 & 12,22 & 3,7 & 45,11 \\
\hline & & & & & & & \\
\hline
\end{tabular}

\section{Pengujian Kinerja Panel Surya monocrystalline $150 \mathrm{Wp}$}

Data pengujian panel surya diambil selama 3 hari, dengan mengambil data tegangan dan arus keluaran pada panel surya serta tegangan dan arus setelah dikenai beban. Beban berupa inverter, tiga buah lampu TL LED 8 watt dan tiga buah aerator.

Hasil pengujian pada panel surya panel surya dapat dilihat pada tabel 1 sampai tabel 3, dan grafik 1 sampai 4.

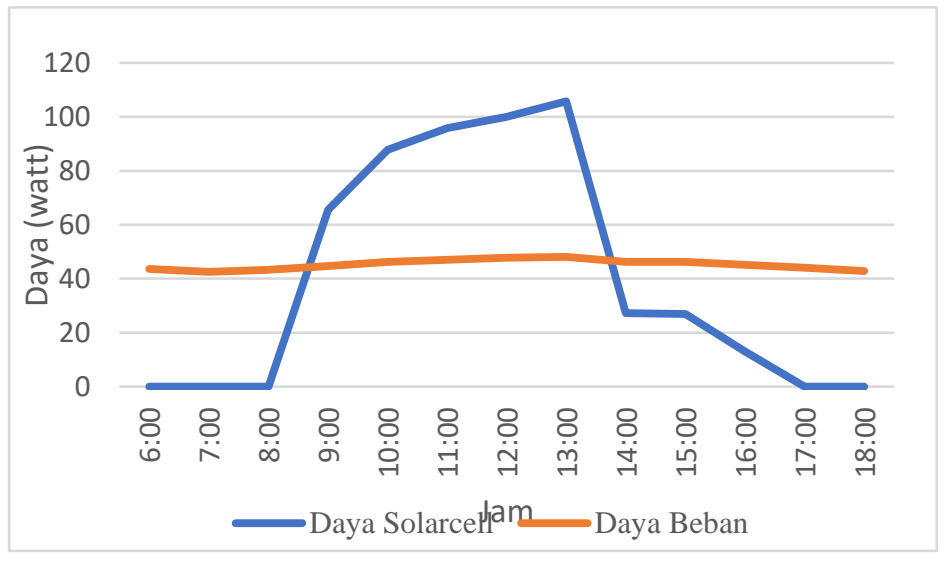

Gambar 1. Daya panel surya dan beban terhadap waktu hari pertama 


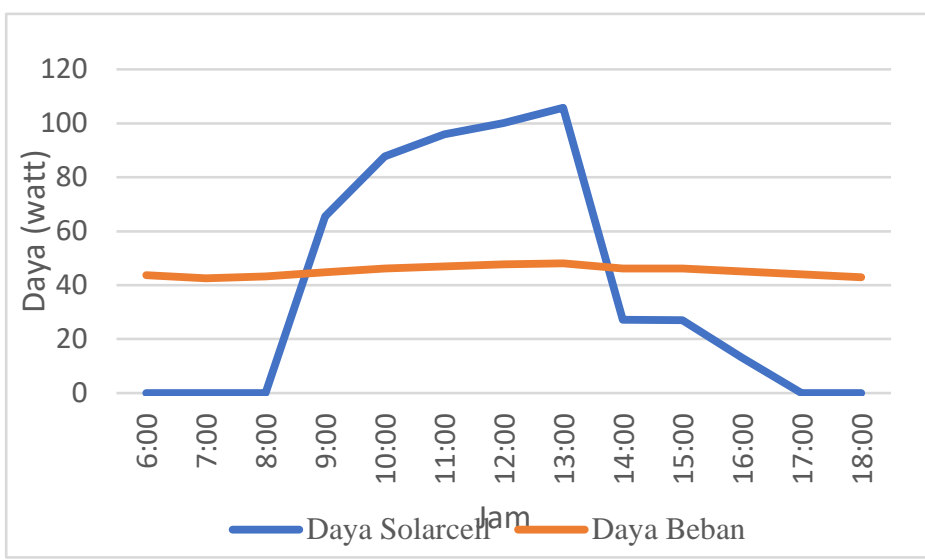

Gambar 2. Daya panel surya dan beban terhadap waktu hari kedua

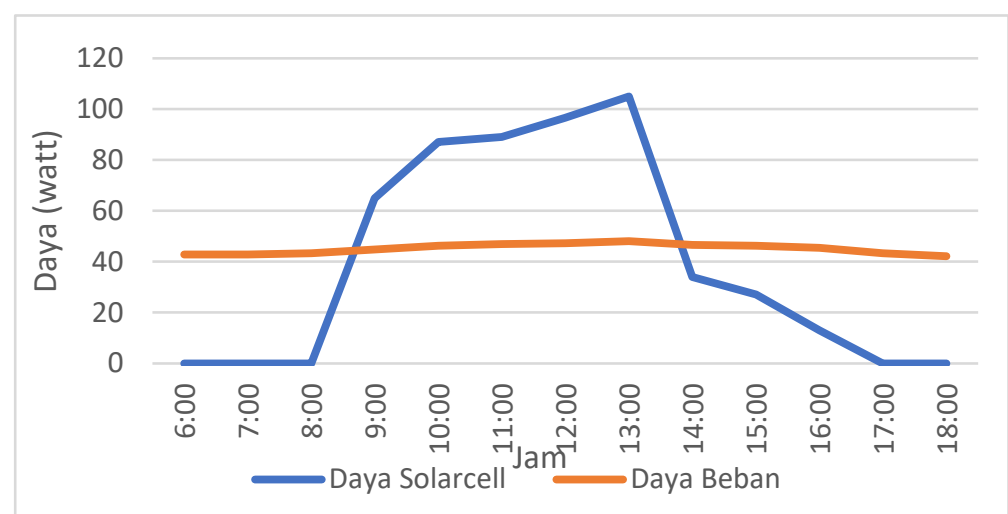

Gambar 3. Daya panel surya dan beban terhadap waktu hari ketiga

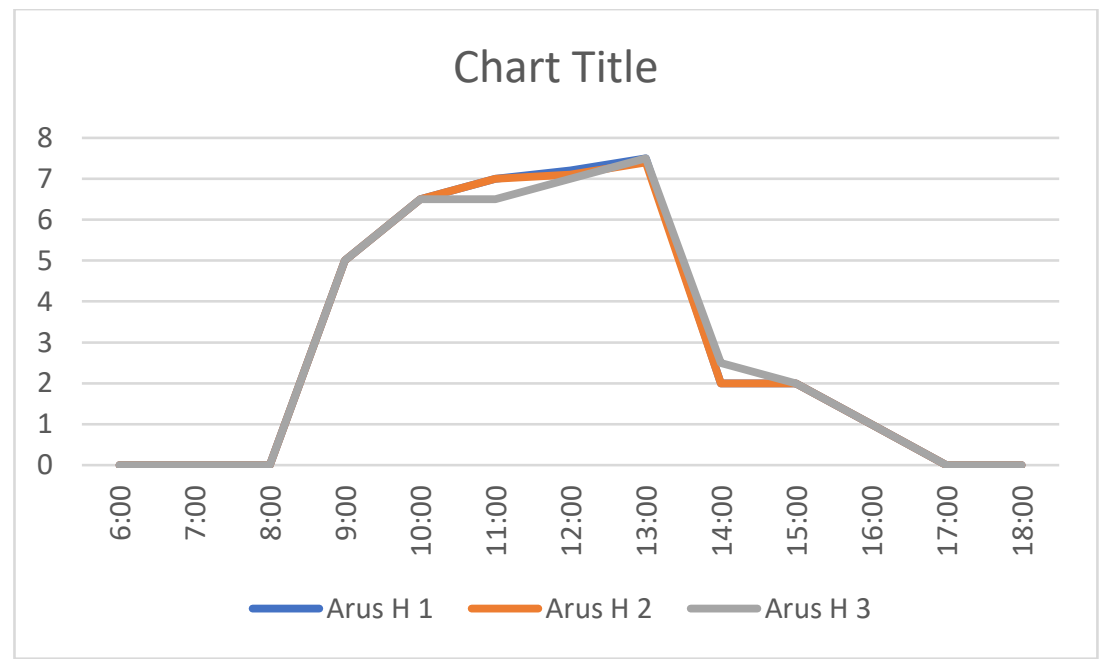

Gambar 4. Arus beban terhadap waktu

Hasil penelitian yang dilakukan dapat dilihat seperti pada tabel 1 sampai tabel 3 tabel pengukuran daya listrik panel surya, sehingga dapat dilakukan analisa perolehan daya pada kondisi terendah saat tegangan sebesar 12,3 volt, arus sebesar 0 ampere, maka daya yang dihasilkan sebesar 0 watt. Kondisi dengan daya sebesar 0 watt terjadi saat pagi hari dan sore hari, sedangkan kondisi daya tertinggi terjadi saat tegangan sebesar 14,1 volt, arus sebesar 7,5 ampere, maka daya yang dihasilkan sebesar 105,75 watt, hal ini terjadi pada saat siang hari pukul 13.00 WIB.

Dengan melihat besar daya yang dihasilkan terhadap jam pengambilan data dapat diketahui bahwa pada siang hari daya yang dihasilkan cukup besar dibandingkan dengan perolehan daya pada saat pagi hari maupun pada saat rkurang sore hari, Berdasarkan tabel data arus yang dihasilkan terhadap waktu (jam) pengambilan data selama tiga hari untuk ketiga hasil pengukuran dapat diketahui bahwa 
pada pagi hari pada saat matahari belum bersinar terik maka arus akan kecil bahkan bisa mencapai nol, namun, semakin siang pada saat matahari bersinar terik maka arus akan semakin bertambah dan menjelang sore arus akan mulai turun dan menjadi nol. Hal ini juga disebabkan karena posisi panel surya yang statis tanpa ada pengaturan gerakan mengikuti arah matahari, sehingga daya setelah jam 13.00 tidak bisa maksimal. Dari kondisi ini dapat diketahui bahwa intensitas cahaya matahari sangat mempengaruhi daya keluaran panel surya, semakin tinggi intensitas cahaya matahari maka semakin tinggi juga arus yang bisa dihasilkan oleh panel surya, sehingga daya yang dihasilkan juga akan semakin besar.

Hasil pengujian Panel Surya monocrystalline $150 \mathrm{Wp}$ menghasilkan daya tertinggi sebesar 105,75 watt dan daya terendah pada 0 watt. Dari grafik antara daya panel surya dan beban menunjukan bahwa pada saat daya panel lebih besar dari beban, maka akan berfungsi sebagai charging baterai dan jika daya panel lebih kecil dari beban, maka daya yang dibutuhkan oleh sistem disuplai oleh baterai. Hal ini menunjukkan bahwa kebutuhan energi listrik sistem kultivasi mikroalga dalam fotobioreaktor dapat terpenuhi oleh sumber energi alternatif dari cahaya matahari dengan menggunakan panel surya.

Berdasarkan tabel 1 sampai dengan tabel 3 data pengukuran beban, berupa tegangan dan arus setelah dikenai beban berupa sebuah inverter, tiga buah lampu TL LED 8 watt dan tiga buah aerator, maka dapat dihitung nilai rata-rata pengukuran, yaitu :

$$
\begin{array}{ll}
\mathrm{V} \text { rata-rata } & =12,22 \mathrm{~V} \\
\mathrm{I} \text { rata-rata } & =3,7 \mathrm{~A} \\
\mathrm{P} \text { rata-rata } & =45,18 \mathrm{Watt}
\end{array}
$$

Sehingga lama waktu yang diperlukan untuk mengisi baterai sebanyak 4 buah dengan kapasitas masingmasing 7 Ah adalah :

$$
\begin{aligned}
& =\frac{(4 \times 7 \mathrm{Ah})}{3,7 \mathrm{~A}} \\
& =\frac{28}{3,7} \\
& =7,6 \mathrm{jam}
\end{aligned}
$$

\section{KESIMPULAN DAN SARAN \\ Kesimpulan}

Berdasarkan hasil penelitian, analisis data serta pembahasan yang telah diperoleh dari pengujian panel surya tipe monocrystalline $150 \mathrm{Wp}$, maka dapat disimpulkan beberapa hal berikut ini :

1. Intensitas cahaya matahari sangat mempengaruhi daya keluaran panel surya, semakin tinggi intensitas cahaya matahari maka semakin tinggi juga arus yang bisa dihasilkan oleh panel surya, sehingga daya yang dihasilkan juga akan semakin besar.

2. Pada saat daya panel surya lebih besar dari beban, maka akan berfungsi sebagai charging baterai dan jika daya panel lebih kecil dari beban, maka daya yang dibutuhkan oleh sistem disuplai oleh baterai.

3. Konsumisi daya setelah dikenai beban adalah 45,18 watt dengan lama waktu pengisian 4 buah baterai 7 Ah adalah selama 7,6 jam.

\section{Saran}

Saran yang dapat diberikan untuk pengembangan selanjutnya diantaranya :

1. Agar cahaya matahari yang ditangkap lebih maksimal maka perlu dikembangkan sistem dinamis dimana posisi panel surya bisa mngikuti arah datangnya cahaya matahari.

2. Agar daya yang tersimpan lebih besar maka jumlah baterai perlu diperhitungkan sehingga energi yang dihasilkan bisa mencukupi kebutuhan sistem.

\section{DAFTAR PUSTAKA}

Anonim dalam Rahayu Kusdarwati,dkk, (2011). Pengaruh Perbedaan Warna Cahaya Terhadap Pertumbuhan Kultur Spirulina sp. Jurnal Ilmiah Perikanan dan Kelautan Vol. 3 No. 2, November 2011, 183.

Arief Budiman, dkk, Mikroalga kultivasi, pemanenan, ekstraksi dan konversi energi, Gama Press, 2019, 61. 
Arif Dwi Santoso, Jurnal Teknik Lingkungan kreteria desain fotobioreaktor sistem airlift reactor, Jakarta 2010, 28.

Astri Rinanti dan Ronny Purwadi, pemanfaatan mikroalga blooming dalam produksi bioethanol tanpa proses hidrolisis, Prosiding Seminar Nasional Kota Berkelanjutan 2018 Astri Rinanti, Ronny Purwadi p-issn 2621-2048/e-issn 2621-2056, 283

Hadiyanto dan maulana azim, mikroalga sumber pangan dan energi masa depan, UPT Undip Perss Semarang, 2012, $15-17$.

Hadiyanto dan Nais P, biorefinery Mikroalga, EF Press Digimedia, semarang 2018, 52.

Heru wahyudi, optimasi plts dengan mengembangkan sistem pengendali panel surya otomatis, Tesis, 2010, 21 - 24. http://solarsuryaindonesia.com, 18 Juni 2020, 21.45

Rislima Sitompul, teknologi energi terbarukan yang tepat untuk aplikasi di masyarakat pedesaan, 2011, 27.

Sari Afriani, dkk, Komposisi kimia spirulina platensis yang dikultivasi dalam fotobioreaktor dengan fotoperiode berbeda, jphpi 2018, volume 21 nomor 3, 472.

Sarman, O.G. (2018). Mikroalga: Sumber Energi Terbarukan Masa Depan, http://journal.trunojoyo.ac.id/jurnalkelautan, Jurnal Kelautan Volume 11, No. 1, 2018, 102 